\title{
The quantified analysis of causes of market risk fluctuations in the group of construction, real estate and construction material companies in Vietnam during and after the global crisis 2007-2011
}

\author{
HOANG THANH HANH \\ Thuong Mai University Ha noi, VIETNAM \\ LE THI VIET NGA \\ Thuong Mai University Ha noi, VIETNAM \\ DINH TRAN NGOC HUY \\ Banking University of Ho Chi Minh cityn VIETNAM \\ LUONG MINH LAN \\ Van Lang University, Ho Chi Minh city, VIETNAM \\ PHAM MINH DAT \\ Thuong Mai University Ha noi, VIETNAM
}

and Graduate School of International Management, International University of Japan, Niigata, JAPAN

\begin{abstract}
This research analyzes the fluctuations on market risk for the listed firms in the Vietnam real estate, construction and construction material industries as it becomes necessary, esp. after the financial crisis 2007-2011. It also provides us with a model to identify key causes of these above risk fluctuations. Firstly, by using quantitative and analytical methods to estimate asset and equity beta of the total 205 listed companies in Vietnam's real estate, construction and construction material industry with a proper traditional model, we found that in the viewpoint of asset beta used as market risk measurement, the construction industry has the lowest risk, next is the construction material industry and real estate one has the highest risk. Secondly, we recognized that in the real estate, construction and construction material industry, the main factors affecting market risk are GDP growth, lending rate, and inflation. Thirdly, by using a proper quantitative analysis method, the study realized that in the viewpoint of asset beta, construction industry has the lowest market risk because of GDP growth decreasing, inflation increasing and average income increasing. On the contrary, real estate industry has the highest market risk because GDP growth decreases and lending rate increases. Finally, this paper provides some outcomes that could provide companies and government with more evidence in establishing their policies in governance and in monitoring these industries.
\end{abstract}

Key-Words: - construction industry, real estate, exchange rate, lending rate, market risk, policy

Received: September 24, 2019. Revised: February 28, 2020. Accepted: March 6, 2020. Published: March 10, 2020.

\section{Introduction}

Vietnam economy experienced high interest rates in 2008, which decreased in 2009 and went up again in 2011 while GDP growth rate reduced in 2009 but recovered in 2010. During the period 2009-2011, the number of real estate transactions in Vietnam declined with huge inventory and real estate price bubble in 2007-2008 has been one of three price bubbles since 1991. In the real estate industry, some companies have investment over their capacity which leads to inprogress projects. In the construction and construction material industry, during difficult economic time, some cement and steel companies reported losses due to lots of inventories, declining purchasing power. And in all three industries, there is pressure of repaying debt and interests and of high production costs.

This paper is organized as follows. The research issues and literature review will be covered in the next sections (2 and 3), for a short summary. Then, methodology and conceptual theories are introduced in sections 4 and 5. Section 6 describes the data in 
empirical analysis. Section 7 presents empirical results and findings. Next, section 8 covers the analytical results. Then, section 9 presents the analysis of risk. Lastly, sections 10 and 11 will present discussion and conclude with some policy suggestions. This paper also supports readers with references, exhibits and relevant web sources. Another point of this paper's usefulness is that it indicates the higher exchange rate and lending rate, the higher market risk. Hence, it contributes to a suitable macro policies for banks and foreign exchange.

\section{Problem Formulation}

\subsection{Research issues}

This study focuses on several issues in the construction company group as followed:

Issue 1: Summarizing market risk fluctuations in the three industries : construction, real estate and construction material

Issue 2: Analyzing the impact of financial leverage (FL) changes on the market risk of three above industries

Issue 3: Identifying causes of the above analysis and giving out some suggestions or solutions.

\subsection{Literature review}

Probably, the most successful models to account for the time-dependent volatility in financial time series are GARCH processes [7].

Findings found that firms which maintain good governance structures have leverage ratios that are higher (forty-seven percent) than those of firms with poor governance mechanisms per unit of profit [13].

Research stated today, the assumption of efficient capital markets is very controversial, especially in these times of crisis, and is challenged by research showing that the pricing was distorted by detection of long memory [4].

Study also indicated in the three factor model that "value" and "size" are significant components which can affect stock returns. They also mentioned that a stock's return not only depends on a market beta, but also on market capitalization beta. The market beta is used in the three factor model, developed by Fama and French, which is the successor to the CAPM model by Sharpe, Treynor and Lintner [3]. Research mentions that equity volatility increases proportionally with the level of financial leverage, the variation of which is dictated by managerial decisions on a company's capital structure based on economic conditions. And for a company with a fixed amount of debt, its financial leverage increases when the market price of its stock declines [1]. Then, as research result pointed, the task of estimating cost of equity in emerging markets is more difficult because of problems such as collecting data in short periods [10]. And study revealed that in different industries in Sri Lanka, the degree of financial leverage has a significant positive correlation with financial risk [6]. Finally, financial leverage can be considered as one among many factors that affect business risk of wholesale and retail firms.

\subsection{Methodology}

In order to estimate systemic risk results and leverage impact, in this study, we use the live data during the crisis period 2007-2011 from the stock exchange market in Vietnam (HOSE and HNX and UPCOM).

In this research, analytical research methods, philosophical methods and specially, leverage scenario analysis methods are used. Analytical data is obtained from the situation of listed wholesale and retail firms in VN stock exchange and the curent tax rate is $25 \%$.

In addition to, quantitative analysis method is used to analyze economic data and identify causes of the empirical findings.

Data is from the stock exchange as followed:

Table 0 - The number of Vietnam listed firms in the three above industries

\begin{tabular}{|l|l|l|l|l|}
\hline Market & $\begin{array}{l}\text { Listed Real Estate } \\
\text { companies (1) }\end{array}$ & $\begin{array}{l}\text { Listed } \\
\text { Construction } \\
\text { companies (2) }\end{array}$ & $\begin{array}{l}\text { Listed } \\
\text { Construction } \\
\text { Material } \\
\text { companies (3) }\end{array}$ & Note (4) \\
\hline Viet Nam & 23 & 77 & 45 & $\begin{array}{l}\text { Estimating by } \\
\text { traditional } \\
\text { method }\end{array}$ \\
\cline { 2 - 5 } & 22 & 27 & 12 & $\begin{array}{l}\text { Estimating by } \\
\text { comparative } \\
\text { method }\end{array}$ \\
\hline Total & $\mathbf{4 4}$ & $\mathbf{1 0 4}$ & $\mathbf{5 7}$ & $\begin{array}{l}\text { Total firms in } \\
\text { groups: 205 }\end{array}$ \\
\hline
\end{tabular}

Finally, we use the results to suggest a policy for these enterprises, relevant organizations and government.

\section{Problem Solution}

The study analyzes data of a total of 205 listed firms in the above three industries on VN stock exchange (HOSE and HNX mainly).

In this part, the current level of financial leverage is kept as in the 2011 financial statements which is used to calculate market risk (beta). Then, quantitative 
analysis with the support of Eview is used to identify causes of the findings.

Market risk (beta) under the impact of the financial leverage, includes: 1) equity beta; and 2) asset beta.

Table 1 - Market risk level in three industries: real estate, construction and construction material

\begin{tabular}{|c|c|c|c|}
\hline Equity beta & $\begin{array}{l}\text { No. of } \\
\text { firms }\end{array}$ & $\begin{array}{c}\text { Financial leverage } \\
\text { (average) }\end{array}$ & Ratio \\
\hline$<0$ & 0 & $0,0 \%$ & $0,0 \%$ \\
\hline $0<$ beta $<1$ & 95 & $62,0 \%$ & $46,1 \%$ \\
\hline Beta $>1$ & 110 & $63,6 \%$ & $53,9 \%$ \\
\hline Total & 205 & $63,2 \%$ & $100,0 \%$ \\
\hline Asset beta & $\begin{array}{l}\text { No. of } \\
\text { firms }\end{array}$ & $\begin{array}{c}\text { Financial leverage } \\
\text { (average) }\end{array}$ & Ratio \\
\hline$<0$ & 0 & $0,0 \%$ & $0,0 \%$ \\
\hline $0<$ beta $<1$ & 196 & $33,5 \%$ & $95,6 \%$ \\
\hline Beta $>1$ & 9 & $130,4 \%$ & $4,4 \%$ \\
\hline Total & 205 & $63,2 \%$ & $100,0 \%$ \\
\hline
\end{tabular}

Table 2 - Market risk level statistic results in real estate, construction and construction material company group 2007-2011

\begin{tabular}{|l|c|c|c|}
\hline Statistic results & $\begin{array}{c}\text { Equity } \\
\text { beta }\end{array}$ & $\begin{array}{c}\text { Asset beta (assume debt } \\
\text { beta }=0 \text { ) }\end{array}$ & Difference \\
\hline MAX & 1,777 & 1,586 & 0,190 \\
\hline MIN & 0,070 & 0,019 & 0,052 \\
\hline MEAN & 0,927 & 0,441 & 0,487 \\
\hline VAR & 0,2468 & 0,1111 & 0,136 \\
\hline \multicolumn{4}{|c|}{ Note: Sample size : 44 (real estate industry) } \\
\hline Statistic results & $\begin{array}{c}\text { Equity } \\
\text { beta }\end{array}$ & $\begin{array}{c}\text { Asset beta (assume debt } \\
\text { beta }=0)\end{array}$ & Difference \\
\hline MAX & 2,884 & 1,458 & 1,427 \\
\hline MIN & 0,115 & 0,008 & 0,107 \\
\hline MEAN & 1,106 & 0,307 & 0,799 \\
\hline VAR & 0,2527 & 0,0640 & 0,189 \\
\hline \multicolumn{4}{|c|}{ Note: Sample size : 104 firms (construction) } \\
\hline Statistic results & $\begin{array}{c}\text { Equity } \\
\text { beta }\end{array}$ & $\begin{array}{c}\text { Asset beta (assume debt } \\
\text { beta = 0) }\end{array}$ & Difference \\
\hline MAX & 3,693 & 1,807 & 1,885 \\
\hline MIN & 0,129 & 0,041 & 0,088 \\
\hline MEAN & 1,011 & 0,456 & 0,554 \\
\hline VAR & 0,2839 & 0,1101 & 0,174 \\
\hline \multicolumn{4}{|c|}{ Note: Sample size : 57 firms (material) } \\
\hline
\end{tabular}

The above table 1 and 2 give us some results: the construction industry has the lowest beta volatility with the gap of 1.45 (between asset beta max and min) while the real estate industry has the second lowest beta volatility (the gap is 1.57), and the construction material has the largest beta volatility (the gap is 1.77).
Furthermore, the construction industry experienced the largest gap between equity and asset beta (0.799), next is the construction material industry (0.554) and the last is the real estate one (0.487). Hence, FL has the most effective impact on the construction industry, next is the construction material industry and the last is the real estate one. It is the construction industry that has the biggest fluctuation between equity and asset beta var, next is the construction material industry and the last is the real estate one.

Chart 1 - Equity and asset beta of construction company group 2007-2011

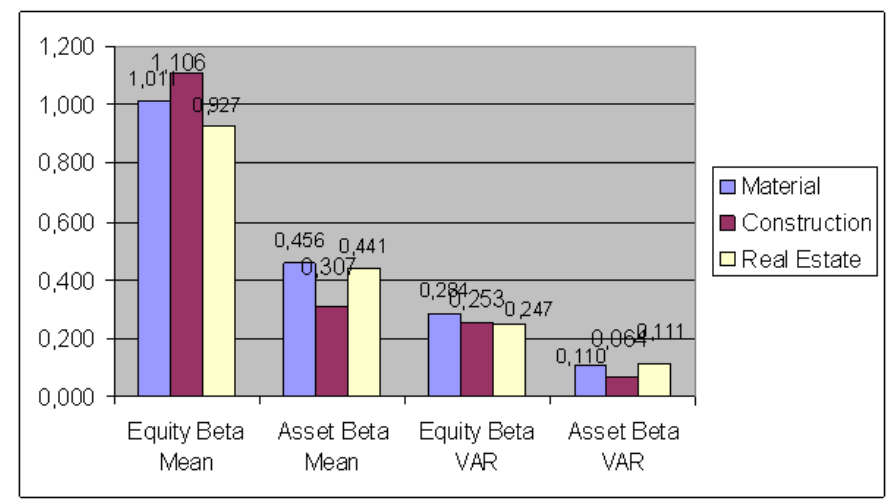

The above chart 1 generates some results:

Equity beta in the construction industry is the highest, and the lowest is in the real estate industry. Asset beta in the construction material industry is the highest, the lowest is in the construction industry.

Then, equity beta volatility in the construction material industry is the highest, the lowest is in the real estate one. Asset beta volatility in the real estate industry is the highest, the lowest is in the construction industry.

Therefore, in the viewpoint of asset beta used as market risk measurement, the construction industry has the lowest risk, next is the construction material industry and real estate one has the highest risk.

\section{The analysis of causes:}

The key reasons of the above findings will be presented in the following section under a quantitative analysis. 
Table 3 - Real estate (asset beta), Equation estimation with Eview 2007-2011

Dependent Variable: SER01

Method: Least Squares

Date: 10/18/15 Time: 16:19

Sample: 18

Included observations: 8

\begin{tabular}{crlll}
\hline \hline Variable & Coefficient & Std. Error & t-Statistic & Prob. \\
\hline \hline C & 0.456655 & 0.051204 & 8.918367 & 0.0711 \\
SER02 & 2.651269 & 0.101478 & 26.12657 & 0.0244 \\
SER03 & -0.000289 & $3.47 \mathrm{E}-05$ & -8.308811 & 0.0763 \\
SER04 & -2.035526 & 0.065618 & -31.02065 & 0.0205 \\
SER05 & $1.98 E-05$ & $3.14 \mathrm{E}-06$ & 6.303296 & 0.1002 \\
SER06 & -7.724202 & 0.227420 & -33.96454 & 0.0187 \\
SER07 & -0.012419 & 0.001496 & -8.299780 & 0.0763 \\
\hline \hline R-squared & 0.999910 & Mean dependent var & 0.253500 \\
Adjusted R-squared & 0.999367 & S.D. dependent var & 0.062658 \\
S.E. of regression & 0.001576 & Akaike info criterion & -10.39685 \\
Sum squared resid & $2.48 E-06$ & Schwarz criterion & -10.32734 \\
Log likelihood & 48.58739 & F-statistic & 1843.110 \\
Durbin-Watson stat & 2.469846 & Prob(F-statistic) & 0.017828 \\
\hline \hline
\end{tabular}

Table 4 - Real estate industry 2007-2011, Descriptive statistics

\begin{tabular}{|l|c|c|c|c|c|c|c|}
\hline & SER01 & SER02 & SER03 & SER04 & SER05 & SER06 & SER07 \\
\hline Mean & 0.253500 & 0.169375 & 430.0750 & 0.131663 & 18499.63 & 0.057438 & 14.65850 \\
\hline Median & 0.278000 & 0.180000 & 446.4500 & 0.125200 & 18370.00 & 0.060250 & 14.36500 \\
\hline Maximum & 0.303000 & 0.220000 & 507.1000 & 0.220000 & 20670.00 & 0.065000 & 17.96200 \\
\hline Minimum & 0.122000 & 0.105000 & 316.3000 & 0.047000 & 16534.00 & 0.039000 & 11.94200 \\
\hline Std. Dev. & 0.062658 & 0.042798 & 70.32276 & 0.059859 & 1676.728 & 0.008702 & 2.871613 \\
\hline Skewness & -1.385901 & -0.359590 & -0.475181 & 0.047405 & 0.181885 & -1.246708 & 0.087718 \\
\hline Kurtosis & 3.409080 & 1.657373 & 1.806648 & 1.803570 & 1.442013 & 3.526955 & 1.118795 \\
\hline & & & & & & & \\
\hline Jarque-Bera & 2.616742 & 0.773289 & 0.775758 & 0.480144 & 0.853218 & 2.164936 & 1.189903 \\
\hline Probability & 0.270260 & 0.679333 & 0.678494 & 0.786571 & 0.652719 & 0.338758 & 0.551589 \\
\hline & & & & & & & \\
\hline Sum & 2.028000 & 1.355000 & 3440.600 & 1.053300 & 147997.0 & 0.459500 & 117.2680 \\
\hline Sum Sq. Dev. & 0.027482 & 0.012822 & 34617.03 & 0.025082 & 19679924 & 0.000530 & 57.72314 \\
\hline & & & & & & & \\
\hline & & 8 & 8 & 8 & 8 & 8 & 8 \\
\hline \hline
\end{tabular}

The above table 3 and 4 show that mean of asset beta is 0.253 and the median is 0.278 (low).

With SER01 = asset beta, SER02=Lending rate, SER03=VNIndex, $\quad$ SER04=inflation, SER05=exchange rate, SER06=GDP growth rate, SER07 $=$ average income per capita, the regression result with Eview gives us:

SER01 $=0.46+2.65$ lendingrate- 0.0003 VnIndex2.04inflation+(1.98E-05)exchangerate7.72GDPgrowth-0.01averageincome (equation 1)

Hence, market risk level or asset beta has the positive relationship with lending rate (strongly, 2.65) and exchange rate. The higher lending rate, the higher market risk.

On the contrary, market risk level or asset beta has the negative relationship with GDP growth (strongly, -
7.72), next is inflation (-2.04), average income ($0.01)$, and $\mathrm{VN}$ index (-0.0003). The higher GDP growth and inflation, the bigger market risk. The higher average income and $\mathrm{VN}$ index, the bigger market risk.

The main factors are GDP growth (-), lending rate (+) and inflation (-).

Table 5 - Construction industry (asset beta), Equation estimation with Eview 2007-2011

\begin{tabular}{|l|c|c|c|c|c|c|c|}
\hline & SER01 & SER02 & SER03 & SER04 & SER05 & SER06 & SER07 \\
\hline Mean & 0.257750 & 0.169375 & 430.0750 & 0.131663 & 18499.63 & 0.057438 & 14.65850 \\
\hline Median & 0.261000 & 0.180000 & 446.4500 & 0.125200 & 18370.00 & 0.060250 & 14.36500 \\
\hline Maximum & 0.309000 & 0.220000 & 507.1000 & 0.220000 & 20670.00 & 0.065000 & 17.96200 \\
\hline Minimum & 0.207000 & 0.105000 & 316.3000 & 0.047000 & 16534.00 & 0.039000 & 11.94200 \\
\hline Std. Dev. & 0.028952 & 0.042798 & 70.32276 & 0.059859 & 1676.728 & 0.008702 & 2.871613 \\
\hline Skewness & -0.042474 & -0.359590 & -0.475181 & 0.047405 & 0.181885 & -1.246708 & 0.087718 \\
\hline Kuntosis & 3.208923 & 1.657373 & 1.806648 & 1.803570 & 1.442013 & 3.526955 & 1.118795 \\
\hline & & & & & & & \\
\hline Jarque-Bera & 0.016955 & 0.773289 & 0.775758 & 0.480144 & 0.853218 & 2.164936 & 1.189903 \\
\hline Probability & 0.991558 & 0.679333 & 0.678494 & 0.786571 & 0.652719 & 0.338758 & 0.551589 \\
\hline & & & & & & & \\
\hline Sum & 2.062000 & 1.355000 & 3440.600 & 1.053300 & 147997.0 & 0.459500 & 117.2680 \\
\hline Sum Sq. Dev. & 0.005868 & 0.012822 & 34617.03 & 0.025082 & 19679924 & 0.000530 & 57.72314 \\
\hline & & & & & & & \\
\hline Observations & 8 & 8 & 8 & 8 & 8 & 8 & 8 \\
\hline
\end{tabular}

Table 6 - Construction industry, 2007-2011, Descriptive statistics

Dependent Variable: SERO1

Method: Least Squares

Date: 10/18/15 Time: 20:08

Sample: 18

Included observations: 8

\begin{tabular}{crlll}
\hline \hline Variable & Coefficient & Std. Error & t-Statistic & Prob. \\
\hline \hline C & -0.404421 & 0.836241 & -0.483618 & 0.7132 \\
SER02 & 0.242636 & 1.657294 & 0.146405 & 0.9075 \\
SER03 & -0.000294 & 0.000567 & -0.518997 & 0.6952 \\
SER04 & -0.887249 & 1.071652 & -0.827926 & 0.5598 \\
SER05 & $7.95 E-05$ & $5.12 E-05$ & 1.551849 & 0.3644 \\
SER06 & 1.798566 & 3.714119 & 0.484251 & 0.7129 \\
SER07 & -0.048349 & 0.024437 & -1.978497 & 0.2979 \\
\hline \hline R-squared & 0.887044 & Mean dependent var & 0.257750 \\
Adjusted R-squared & 0.209308 & S.D. dependent var & 0.028952 \\
S.E. of regression & 0.025744 & Akaike info criterion & -4.810648 \\
Sum squared resid & 0.000663 & Schwarz criterion & -4.741136 \\
Log likelihood & 26.24259 & F-statistic & 1.308834 \\
Durbin-Watson stat & 2.469846 & Prob(F-statistic) & 0.584321 \\
\hline \hline
\end{tabular}

The above table 5 and 6 show that mean of asset beta is 0.257 and the median is 0.261 (lower than that of real estate industry).

The regression result with Eview gives us:

\section{SER01 $=-0.4+0.24$ lendingrate -0.0003 VNIndex - 0.89inflation + 7.95Eexchangerate + 1.8GDPgrowth -0.05averageincome (equation 2)}

Hence, market risk level or asset beta has the positive relationship with GDP growth rate $(1.8$, differ from 
real estate), lending rate (0.24) and exchange rate. The higher GDP growth and lending rate, the higher market risk. On the contrary, market risk level or asset beta has the negative relationship with inflation ($0.89)$, next is average income per capita $(-0.05)$, and VN index (-0.0003). The lower inflation and VNIndex and average income, the bigger market risk. The higher average income and $\mathrm{VN}$ index, the bigger market risk. The main factors are GDP growth $(+$, differ from real estate and construction material), inflation (-) and lending rate (+).

Table 7 - Construction material industry, (asset beta), Equation estimation with Eview 2007-2011

\begin{tabular}{|c|c|c|c|c|}
\hline \multicolumn{5}{|c|}{$\begin{array}{l}\text { Dependent Variable: SER01 } \\
\text { Method: Least Squares } \\
\text { Date: } 10 / 18 / 15 \text { Time: } 20: 15 \\
\text { Sample: } 18 \\
\text { Included observations: } 8\end{array}$} \\
\hline Variable & Coefficient & Std. Error & t-Statistic & Prob. \\
\hline C & -0.028193 & 0.751824 & -0.037500 & 0.9761 \\
\hline SER02 & 0.669226 & 1.489995 & 0.449147 & 0.7313 \\
\hline SER03 & -0.000232 & 0.000510 & -0.455674 & 0.7278 \\
\hline SER04 & -0.768368 & 0.963472 & -0.797499 & 0.5714 \\
\hline SER05 & 3.91E-05 & 4.60E-05 & 0.848633 & 0.5520 \\
\hline SER06 & -1.319138 & 3.339190 & -0.395047 & 0.7605 \\
\hline SER07 & -0.025274 & 0.021971 & -1.150365 & 0.4556 \\
\hline R-squared & 0.830040 & Mean depe & dent var & 0.160500 \\
\hline Adjusted R-squared & -0.189720 & S.D. depen & lent var & 0.021220 \\
\hline S.E. of regression & 0.023145 & Akaike info & criterion & -5.023475 \\
\hline Sum squared resid & 0.000536 & Schwarz $\mathrm{cr}$ & erion & -4.953963 \\
\hline Log likelihood & 27.09390 & F-statistic & & 0.813956 \\
\hline Durbin-Watson stat & 2.469846 & Prob(F-stat & stic) & 0.689872 \\
\hline
\end{tabular}

Table 8 - Construction material industry, 20072011, Descriptive statistics

\begin{tabular}{|l|c|c|c|c|c|c|c|}
\hline & SER01 & SER02 & SER03 & SERO4 & SER05 & SER06 & SER07 \\
\hline Mean & 0.160500 & 0.169375 & 430.0750 & 0.131663 & 18499.63 & 0.057438 & 14.65850 \\
\hline Median & 0.163500 & 0.180000 & 446.4500 & 0.125200 & 18370.00 & 0.060250 & 14.36500 \\
\hline Maximum & 0.186000 & 0.220000 & 507.1000 & 0.220000 & 20670.00 & 0.065000 & 17.96200 \\
\hline Minimum & 0.112000 & 0.105000 & 316.3000 & 0.047000 & 16534.00 & 0.039000 & 11.94200 \\
\hline Std. Dev. & 0.021220 & 0.042798 & 70.32276 & 0.059859 & 1676.728 & 0.008702 & 2.871613 \\
\hline Skewness & -1.540867 & -0.359590 & -0.475181 & 0.047405 & 0.181885 & -1.246708 & 0.087718 \\
\hline Kurtosis & 4.802755 & 1.657373 & 1.806648 & 1.803570 & 1.442013 & 3.526955 & 1.118795 \\
\hline & & & & & & & \\
\hline Jarque-Bera & 4.249004 & 0.773289 & 0.775758 & 0.480144 & 0.853218 & 2.164936 & 1.189903 \\
\hline Probability & 0.119492 & 0.679333 & 0.678494 & 0.786571 & 0.652719 & 0.338758 & 0.5551589 \\
\hline & & & & & & & \\
\hline Sum & 1.284000 & 1.355000 & 3440.600 & 1.053300 & 147997.0 & 0.459500 & 117.2680 \\
\hline Sum Sq. Dev. & 0.003152 & 0.012822 & 34617.03 & 0.025082 & 19679924 & 0.000530 & 57.72314 \\
\hline & & & & & & & \\
\hline Observations & 8 & 8 & 8 & 8 & 8 & 8 & 8 \\
\hline
\end{tabular}

The above table 7 and 8 show that mean of asset beta is 0.161 and the median is 0.164 (lower than those of real estate and construction industry). The regression result with Eview gives us:

\section{SER01 $=\mathbf{- 0 . 0 3}+0.7$ lendingrate $-\mathbf{0 . 0 0 0 2 V N I n d e x ~ - ~}$ 0.77inflation $+3.91 \mathrm{E} *$ exchangerate 1.32GDPgrowth -0.03averageincome (equation 3)}

Hence, market risk level or asset beta has the positive relationship with lending rate (0.7) and exchange rate. The higher exchange rate and lending rate, the higher market risk. On the contrary, market risk level or asset beta has the negative relationship with GDP growth (-1.32), inflation (-0.77), next is average income per capita (-0.03), and VN index (-0.0002). The lower inflation, GDP growth, and VNIndex and average income, the bigger market risk. The higher average income and $\mathrm{VN}$ index, the bigger market risk.

The main factors are GDP growth (-, differ from construction), inflation (-) and lending rate (+).

Table 9 - Real estate (equity beta), Equation estimation with Eview 2007-2011

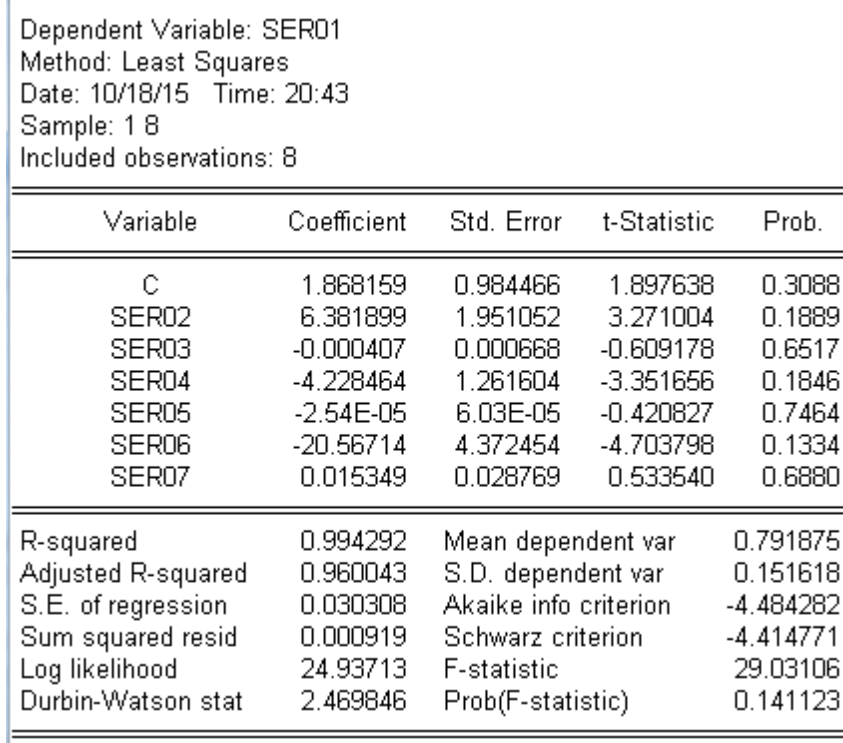

Table 10 - Real estate 2007-2011, Descriptive statistics

\begin{tabular}{|l|c|c|c|c|c|c|c|}
\hline & SER01 & SER02 & SER03 & SER04 & SER05 & SER06 & SER07 \\
\hline Mean & 0.791875 & 0.169375 & 430.0750 & 0.131663 & 18499.63 & 0.057438 & 14.65850 \\
\hline Median & 0.855500 & 0.180000 & 446.4500 & 0.125200 & 18370.00 & 0.060250 & 14.36500 \\
\hline Maximum & 0.917000 & 0.220000 & 507.1000 & 0.220000 & 20670.00 & 0.065000 & 17.96200 \\
\hline Minimum & 0.512000 & 0.105000 & 316.3000 & 0.047000 & 16534.00 & 0.039000 & 11.94200 \\
\hline Std. Dev. & 0.151618 & 0.042798 & 70.32276 & 0.059859 & 1676.728 & 0.008702 & 2.871613 \\
\hline Skewness & -1.138417 & -0.359590 & -0.475181 & 0.047405 & 0.181885 & -1.246708 & 0.087718 \\
\hline Kurtosis & 2.527434 & 1.657373 & 1.806648 & 1.803570 & 1.442013 & 3.526955 & 1.118795 \\
\hline & & & & & & & \\
\hline Jarque-Bera & 1.802430 & 0.773289 & 0.775758 & 0.480144 & 0.853218 & 2.164936 & 1.189903 \\
\hline Probability & 0.406076 & 0.679333 & 0.678494 & 0.786571 & 0.652719 & 0.338758 & 0.551589 \\
\hline & & & & & & & \\
\hline Sum & 6.335000 & 1.355000 & 3440.600 & 1.053300 & 147997.0 & 0.459500 & 117.2680 \\
\hline Sum Sq. Dev. & 0.160917 & 0.012822 & 34617.03 & 0.025082 & 19679924 & 0.000530 & 57.72314 \\
\hline & & & & & & & \\
\hline Obsemations & 8 & 8 & 8 & 8 & 8 & 8 & 8 \\
\hline
\end{tabular}

The above table 9 and 10 show that mean of equity beta is 0.792 and the median is 0.855 (lower than 1 ). 
The regression result with Eview gives us:

\section{SER01 $=1.87+6.38$ lendingrate -0.0004 VNIndex - 4.23inflation - $2.54 \mathrm{E}^{*}$ exchangerate - 20.57GDPgrowth +0.02 averageincome (equation 4)}

Hence, market risk level or equity beta has the positive relationship with lending rate (strongly, 6.38) and average income (0.02). The higher average income and lending rate, the higher market risk.

On the contrary, market risk level or asset beta has the negative relationship with GDP growth (strongly, 20.57), inflation (-4.23), next is $\mathrm{VN}$ index (-0.0004) and exchange rate (2.54E). The lower inflation, GDP growth, and VNIndex and exchange rate, the bigger market risk.

The main factors are GDP growth (-), inflation (-) and lending rate $(+)$.

Table 11 - Construction (equity beta), Equation estimation with Eview 2007-2011

\begin{tabular}{|c|c|c|c|c|}
\hline \multicolumn{5}{|c|}{$\begin{array}{l}\text { Dependent Variable: SER01 } \\
\text { Method: Least Squares } \\
\text { Date: } 10 / 18 / 15 \text { Time: } 20: 53 \\
\text { Sample: } 18 \\
\text { Included observations: } 8\end{array}$} \\
\hline Variable & Coefficient & Std. Error & t-Statistic & Prob. \\
\hline C & -2.262587 & 4.449480 & -0.508506 & 0.7005 \\
\hline SER02 & 1.389702 & 8.818151 & 0.157596 & 0.9005 \\
\hline SER03 & -0.001475 & 0.003017 & -0.488850 & 0.7105 \\
\hline SER04 & -4.785794 & 5.702062 & -0.839309 & 0.5555 \\
\hline SER05 & 0.000429 & 0.000272 & 1.575600 & 0.3600 \\
\hline SER06 & 9.190803 & 19.76214 & 0.465071 & 0.7229 \\
\hline SER07 & -0.260902 & 0.130027 & -2.006524 & 0.2943 \\
\hline R-squared & 0.888117 & \multicolumn{2}{|c|}{ Mean dependent var } & 1.352500 \\
\hline Adjusted R-squared & 0.216818 & \multicolumn{2}{|c|}{ S.D. dependent var } & 0.154785 \\
\hline S.E. of regression & 0.136981 & \multicolumn{2}{|c|}{ Akaike info criterion } & -1.467395 \\
\hline Sum squared resid & 0.018764 & \multicolumn{2}{|c|}{ Schwarz criterion } & -1.397884 \\
\hline Log likelihood & 12.86958 & \multicolumn{2}{|c|}{ F-statistic } & 1.322982 \\
\hline Durbin-Watson stat & 2.469846 & \multicolumn{2}{|c|}{ Prob(F-statistic) } & 0.581958 \\
\hline
\end{tabular}

Table 12 - Construction industry 2007-2011, Descriptive statistics

\begin{tabular}{|c|c|c|c|c|c|c|c|}
\hline & SER01 & SER02 & SER03 & SER04 & SER05 & SER06 & SER07 \\
\hline Mean & 1.352500 & 0.169375 & 430.0750 & 0.131663 & 18499.63 & 0.057438 & 14.65850 \\
\hline Median & 1.375000 & 0.180000 & 446.4500 & 0.125200 & 18370.00 & 0.060250 & 14.36500 \\
\hline Maximum & 1.616000 & 0.220000 & 507.1000 & 0.220000 & 20670.00 & 0.065000 & 17.96200 \\
\hline Minimum & 1.071000 & 0.105000 & 316.3000 & 0.047000 & 16534.00 & 0.039000 & 11.94200 \\
\hline Std. Dev. & 0.154785 & 0.042798 & 70.32276 & 0.059859 & 1676.728 & 0.008702 & 2.871613 \\
\hline Skewness & -0.220446 & -0.359590 & -0.475181 & 0.047405 & 0.181885 & -1.246708 & 0.087718 \\
\hline Kurtosis & 3.212854 & 1.657373 & 1.806648 & 1.803570 & 1.442013 & 3.526955 & 1.118795 \\
\hline Jarque-Bera & 0.079898 & 0.773289 & 0.775758 & 0.480144 & 0.853218 & 2.164936 & 1189903 \\
\hline Probability & 0.960839 & 0.679333 & 0.678494 & 0.786571 & 0.652719 & 0.338758 & 0.551589 \\
\hline Sum & 10.82000 & 1.355000 & 3440.600 & 1053300 & 1479970 & 0.459500 & 1172680 \\
\hline Sum Sq. Dev. & 0.167708 & 0.012822 & 34617.03 & 0.025082 & 19679924 & 0.000530 & 57.72314 \\
\hline & & & & & & & \\
\hline Observations & 8 & 8 & 8 & 8 & 8 & 8 & 8 \\
\hline
\end{tabular}

The above table 11 and 12 show that mean of equity beta is 1.352 and the median is 1.375 (higher than 1 and than that of real estate).

The regression result with Eview gives us:

\section{SER01 $=-\mathbf{2 . 2 6}+1$ 1.39lendingrate $-\mathbf{0 . 0 0 2}$ VNIndex - 4.79inflation $+\quad 0.0004$ exchangerate + 9.19GDPgrowth -0.26averageincome (equation 5)}

Hence, market risk level or equity beta has the positive relationship with GDP growth (strongly, 9.19), lending rate (1.39) and exchange rate (0.0004). The higher GDP growth, exchange rate and lending rate, the higher market risk. On the contrary, market risk level or asset beta has the negative relationship with inflation (-4.79), next is average income $(-0.26)$ and VNIndex (-0.002). The lower inflation, average income, and VNIndex and exchange rate, the bigger market risk.

The main factors are GDP growth $(+$, differ from real estate), inflation (-) and lending rate (+). 
Table 13 - Construction material (equity beta), Equation estimation with Eview 20072011

\begin{tabular}{|c|c|c|c|c|}
\hline \multicolumn{5}{|c|}{$\begin{array}{l}\text { Dependent Variable: SER01 } \\
\text { Method: Least Squares } \\
\text { Date: } 10 / 18 / 15 \text { Time: } 20: 57 \\
\text { Sample: } 18 \\
\text { Included observations: } 8\end{array}$} \\
\hline Variable & Coefficient & Std. Error & t-Statistic & Prob. \\
\hline C & -0.198506 & 3.814997 & -0.052033 & 0.9669 \\
\hline SER02 & 3.287835 & 7.560708 & 0.434858 & 0.7389 \\
\hline SER03 & -0.001140 & 0.002587 & -0.440699 & 0.7357 \\
\hline SER04 & -3.775774 & 4.888964 & -0.772306 & 0.5813 \\
\hline SER05 & 0.000201 & 0.000234 & 0.860885 & 0.5475 \\
\hline SER06 & -6.314386 & 16.94411 & -0.372660 & 0.7729 \\
\hline SER07 & -0.129616 & 0.111485 & -1.162631 & 0.4522 \\
\hline R-squared & 0.827324 & \multicolumn{2}{|c|}{ Mean dependent var } & 0.828250 \\
\hline Adjusted R-squared & -0.208731 & \multirow{2}{*}{\multicolumn{2}{|c|}{ S.D. dependent var }} & 0.106827 \\
\hline S.E. of regression & 0.117448 & \multirow{2}{*}{\multicolumn{2}{|c|}{$\begin{array}{l}\text { Akaike info criterion } \\
\text { Schwarz criterion }\end{array}$}} & -1.775090 \\
\hline Sum squared resid & 0.013794 & & & -1.705579 \\
\hline Log likelihood & 14.10036 & \multicolumn{2}{|c|}{ F-statistic } & 0.798533 \\
\hline Durbin-Watson stat & 2.469846 & \multicolumn{2}{|c|}{ Prob(F-statistic) } & 0.694096 \\
\hline
\end{tabular}

Table 14 - Construction material 2007-2011, Descriptive statistics

\begin{tabular}{|l|c|c|c|c|c|c|c}
\hline & SER01 & SER02 & SER03 & SER04 & SER05 & SER06 & SER07 \\
\hline Mean & 0.828250 & 0.169375 & 430.0750 & 0.131663 & 18499.63 & 0.057438 & 14.65850 \\
\hline Median & 0.843500 & 0.180000 & 446.4500 & 0.125200 & 18370.00 & 0.060250 & 14.36500 \\
\hline Maximum & 0.963000 & 0.220000 & 507.1000 & 0.220000 & 20670.00 & 0.065000 & 17.96200 \\
\hline Minimum & 0.587000 & 0.105000 & 316.3000 & 0.047000 & 16534.00 & 0.039000 & 11.94200 \\
\hline Std. Dev. & 0.106827 & 0.042798 & 70.32276 & 0.059859 & 1676.728 & 0.008702 & 2.871613 \\
\hline Skewness & -1.436915 & -0.359590 & -0.475181 & 0.0474405 & 0.181885 & -1.246708 & 0.067718 \\
\hline Kurtosis & 4.665795 & 1.657373 & 1.806648 & 1.803570 & 1.442013 & 3.526955 & 1.118795 \\
\hline & & & & & & & \\
\hline & & & & & & & \\
\hline Jarque-Bera & 3.677924 & 0.773289 & 0.775758 & 0.480144 & 0.853218 & 2.164936 & 1.189903 \\
\hline Probability & 0.158982 & 0.679333 & 0.678494 & 0.786571 & 0.652719 & 0.338758 & 0.551589 \\
\hline & & & & & & & \\
\hline Sum & 6.626000 & 1.355000 & 3440.600 & 1.053300 & 147997.0 & 0.459500 & 117.2680 \\
\hline Sum Sq. Dev. & 0.079884 & 0.012822 & 34617.03 & 0.025082 & 19679924 & 0.000530 & 57.72314 \\
\hline & & & & & & & \\
\hline & 8 & 8 & 8 & 8 & 8 & 8 & 8 \\
\hline
\end{tabular}

The above table 13 and 14 show that mean of equity beta is 0.828 and the median is 0.843 (lower than 1 and than those of construction and real estate).

The regression result with Eview gives us:

\section{SER01 $=-0.2+3.29$ lendingrate -0.001 VNIndex - 3.78inflation +0.0002 exchangerate - 6.31GDPgrowth -0.13averageincome (equation 6)}

Hence, market risk level or equity beta has the positive relationship with lending rate (3.29) and exchange rate $(0.0002)$. The higher exchange rate and lending rate, the higher market risk.
On the contrary, market risk level or asset beta has the negative relationship with GDP growth (-6.31), inflation (-3.78), next is average income $(-0.13)$ and VNIndex (-0.001). The lower inflation, average income, and VNIndex and GDP growth rate, the bigger market risk.

The main factors are GDP growth (-, differ from construction), inflation (-) and lending rate $(+)$.

\section{Analysis of causes:}

Comparing three (3) industries (+: positive, :negative), market risk measured by equity beta depends mainly on GDP growth, with the highest level in real estate industry (-20.57), next is construction $(+9.19)$ and the last is construction material (-6.31). Next, market risk measured by equity beta depends on inflation, with the highest level in construction industry (-4.79), next is real estate (-4.23) and the last is construction material ($3.78)$. The next factor is lending rate, with the highest level in real estate industry $(+6.38)$, next is construction material $(+3.29)$ and the last is construction $(+1.39)$.

And market risk measured by equity beta depends little on average income, with the highest level in construction industry (-0.26), next is construction material $(-0.13)$ and the last is real estate $(+0.02)$.

Looking at exhibit $1,2,3,4,5$, showing that:

First, GDP growth rate trend decreasing over years 2007-2011 (exhibit 1) makes:

- Real estate industry: equity beta increases, asset beta increases

- Construction industry: equity beta decreases, asset beta decreases

- Construction material industry: equity beta increases, asset beta increases

Second, lending interest rate trend increasing over years 2007-2011 (exhibit 2) makes:

- Real estate industry: equity beta increases, asset beta increases

- Construction industry: equity beta increases, asset beta increases

- Construction material industry: equity beta increases, asset beta increases 
Third, inflation trend slightly increasing over years 2007-11 (exhibit 3) makes:

- Real estate industry: equity beta decreases, asset beta decreases

- Construction industry: equity beta decreases, asset beta decreases

- Construction material industry: equity beta decreases, asset beta decreases

Average income per capita trend increasing over years 2007-11 (exhibit 4) makes:

- Real estate industry: equity beta increases, asset beta decreases

- Construction industry: equity beta decreases, asset beta decreases

- Construction material industry: equity beta decreases, asset beta decreases

From the above analysis, it is noted that equity beta in the construction industry is the highest because of increasing lending rate trend. Equity beta in the real estate industry is the lowest due to increasing inflation trend. And in the viewpoint of asset beta, construction industry has the lowest market risk because GDP growth decreases, inflation increases and average income increases. On the contrary, real estate industry has the highest market risk because GDP growth decreases and lending rate increases.

\section{Discussion}

Real estate industry has the highest market risk measured by asset beta. Other special reasons are: the number of real estate transactions decreasing, limited real estate loans with high rates. Other reasons include: a tightening monetary policy performed in 2008, global economic crisis impact and companies' high stock pricing. The impact of high market risk in the real estate industry is that investors might expect a higher ROI, as we can see in the below SML chart showing the relationship between beta and expected return:

\section{Chart 2 - Security market line (SML)}

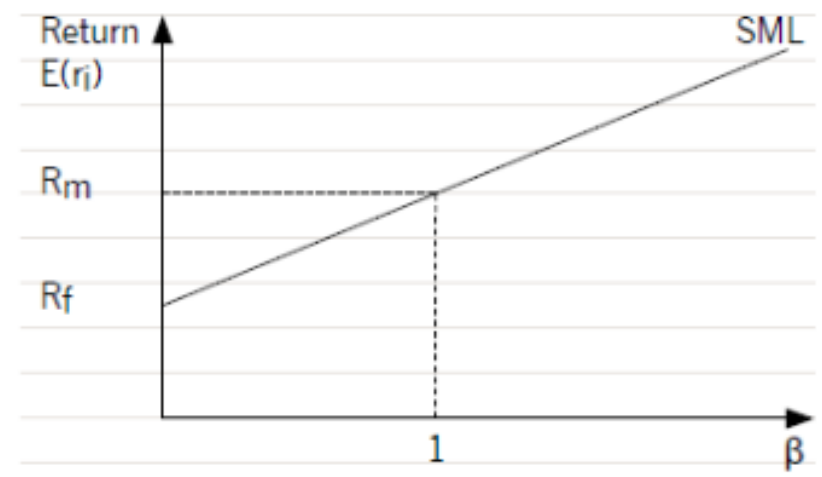

Next, a high beta in real estate industry can lead to a high cost of equity and high cost of capital. Hence, NPV of these firms' projects or firms' value will decrease.

\section{Conclusion and Policy suggestion}

Real estate industry: considering target inflation policy with proper controlled growth rate in order to reduce market risk, other policies including supporting GDP growth and reducing lending interest rates. Construction industry: suggesting reasonable salary and wage increasing policy stage-by-stage and creating more jobs in order to reduce market risk. Construction material industry: encouraging GDP growth policy, lending rate reducing plans and target inflation policy with proper controlled growth rate in order to reduce market risk. Last but not least, the government has to consider the impact on the mobility of capital in the markets when it changes its macroeconomic policies whilst continuing to increase the effectiveness of building the legal system and regulation supporting the plan of developing the real estate, construction material and construction market. Impacts of this paper in financial engineering: real estate market need to receive more financial products to recover after economic recession, esp. during this stage. Applications of this paper in banking industry: because lending rate has positive correlation with market risk, banks are in favor of decreasing lending rates will help to reduce market risk.

\section{Declaration of Conflicting Interests}

The authors declared no potential conflicts of interest with respect to the research, authorship, and/ or publication of this article.

References:

[1] Carr, Peter., and Wu, Liuren. (2007), Leverage Effect, Volatility Feedback, and Self-Exciting Market Disruptions, SSRN Working Paper 
[2] Chen, K.C., Wu, Lifan., and Wen, Jian. (2013), The Relationship Between Finance and Growth in China, Global Finance Journal

[3] Eugene, Fama F., and French, Kenneth R. (2004), The Capital Asset Pricing Model: Theory and Evidence, Journal of Economic Perspectives

[4] Flifel, Kaouther., (2012), Financial Markets between Efficiency and Persistence : Empirical Evidence on Daily Data, Asian Journal of Finance and Accounting

[5] Gabrijelcic M., Herman U., and Lenarcic A., (2013), Debt Financing and Firm Performance Before and During the Crisis: Micro-Financial Evidence from Slovenia, SSRN Working Paper

[6] Gunarathna, V. (2013), Degree of Financial Leverage as a Determinant of Financial Risk : An Empirical Study in Sri Lanka, SSRN Working Paper

[7] Hamilton, J. D. (1994). Time Series Analysis. Princeton University Press.

[8] Huy, Dinh T.N., (2012), Estimating Beta of Vietnam listed construction companies groups during the crisis, Journal of Integration and Development

[9] Ngo Chi Thanh, Nguyen Duy Dat, Nguyen Dac Anh Chuong, Dinh Tran Ngoc Huy. (2020). A Business Model for Producing Clean Energy in Developing Countries, WSEAS Transactions on Business and Economics, 17, 75-84

[10] Pereiro, Luis E. (2010), The Beta Dilemma in Emerging Markets, Journal of Applied Corporate Finance

[11] Pham Tuan Anh, Dinh Van Son, Dinh Tran Ngoc Huy. (2019). Risk Management via Measuring the Volatility of Market Risk of Vietnam Hardware Industry during the Post-Low Inflation 2015-2017, WSEAS Transactions on Business and Economics, $16,552-558$

[12] Shahrokhi, Manuchehr. (2010), the Global Financial Crises of 2007-2010 and The Future of Capitalism, Global Finance Journal

[13] Umar., (2011), Profits, Financial Leverage and Corporate Governance. SSRN Working Paper.

[14] http://www.ifc.org/ifcext/mekongpsdf.nsf/Content/ PSDP22

[15] http://www.mofa.gov.vn/vi/

[16] http://www.hsx.vn/hsx/

[17] www.tuoitre.com.vn;

[18] www.saigontimes.com.vn;

[19] www.mof.gov.vn ;

[20] www.vneconomy.com.vn ;

[21] www.sbv.gov.vn.

\section{Exhibit}

Exhibit 1- VNI Index in VN 2007-2011 (declining)

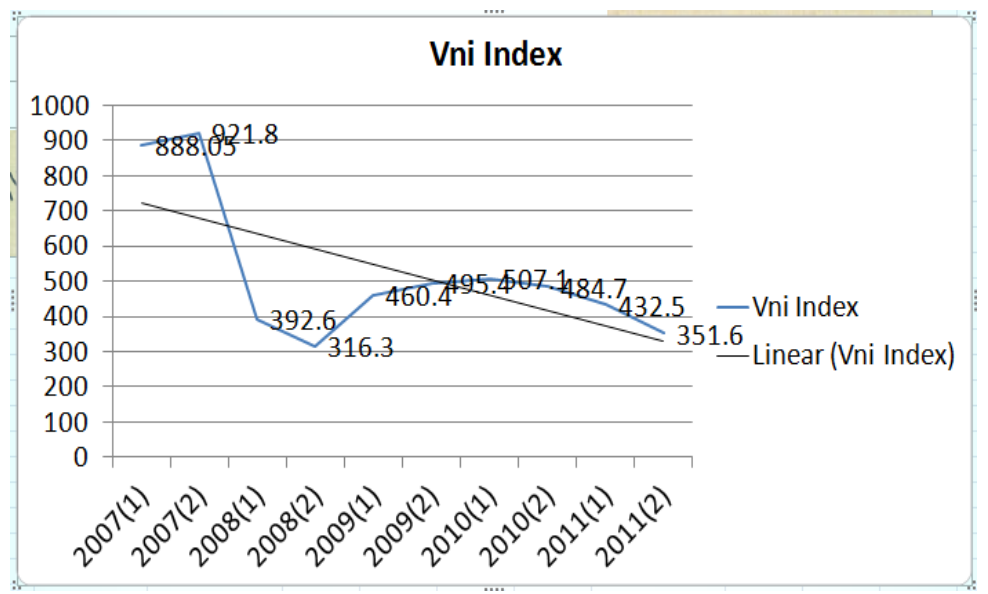

Exhibit 2- USD Exchange rate in VN 2007-2011

(increasing)

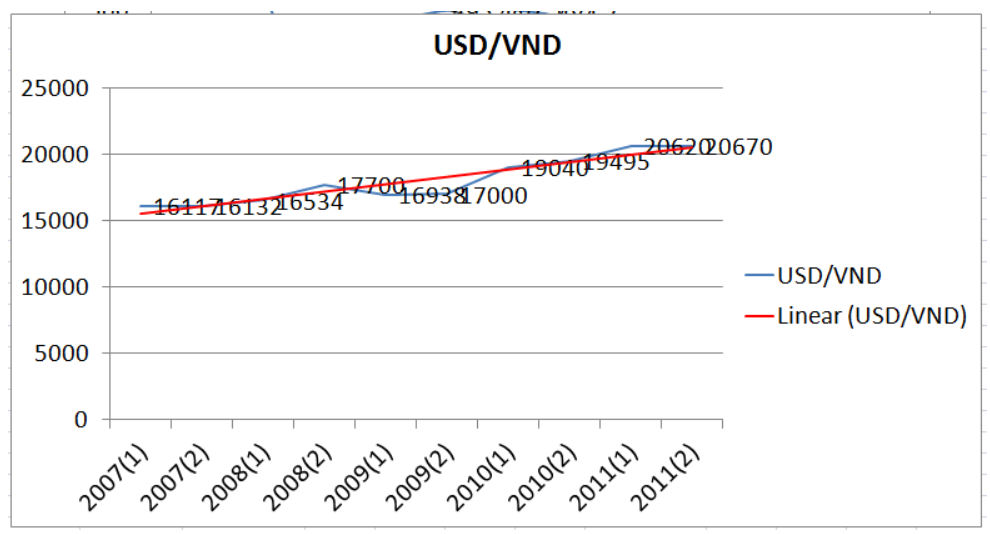

